\title{
Investigation of Detected by Recent Various Human Papillomavirus from General Hospital in Seoul Area
}

\author{
Jun-Beom Lee ${ }^{1,2}$, Chang-Eun Park ${ }^{2,3}$ \\ ${ }^{1}$ Department of Pathology, Gangnam CHA Hospital, Seoul 06135, Korea \\ ${ }^{2}$ Graduate School of Biomedical Laboratory Science, Namseoul University, Cheonan 31020, Korea \\ ${ }^{3}$ Department of Biomedical Laboratory Science, Molecular Diagnostics Research Institute, Namseoul University, Cheonan 31020, Korea
}

\section{최근 서울지역 종합병원에서 다양한 인유두종바이러스의 검출에 대한 실태조사}

\author{
이준범 ${ }^{1,2}$, 박창은 ${ }^{2,3}$ \\ ${ }^{1}$ 강남차병원 병리과, ${ }^{2}$ 남서울대학교 대학원 임상병리학과, ${ }^{3}$ 남서울대학교 임상병리학과, 분자진단연구소
}

\begin{abstract}
Human papillomavirus (HPV) infection is a necessary precondition of cervical cancer. A change from cytology to molecular HPV testing is, however, challenging. A new HPV DNA chip test for the infection of 22 HPV genotypes were developed in Korea. The purpose of this study was to investigate the prevalence and genotype distribution of HPV infection in the Seoul area. Over the last year, a total of 5,614 samples were tested. Using a chip test, HPV genotypes were detected in 1,596 (28.4\%); of which, 679 (42.5\%) were considered as high risk and low risk HPV were 152 (9.5\%). 831 were single positive samples $(n=1596)$. The most frequently found genotypes in all HPV-single positive samples ( $n=831)$ were HPV-16 $(16.5 \%), 58(15.2 \%), 52(8.8 \%), 51(7.1 \%)$ and $56(5.9 \%)$. Mixed genotypes ( $n=219)$ were detected in $2(n=176,11.0 \%), 3(n=37,5.9 \%)$, and 4 $(n=2,0.1 \%)$ positive samples ( $n=1596)$. This study demonstrated that epidemical investigated HPV infection in patients of general hospital. These findings could be used to indicate a nationwide distribution of HPV and the adoption of vaccines. It is hoped that additional epidemiological research regarding the outcomes that are important to decision makers will be conducted.
\end{abstract}

Key words: DNA Chip, Genotype, Human papillomavirus.

This is an Open Access article distributed under the terms of the Creative Commons Attribution Non-Commercial License (http://creativecommons.org/licenses/by-nc/4.0) which permits unrestricted non-commercial use, distribution, and reproduction in any medium, provided the original work is properly cited.

Copyright @ 2016 The Korean Society for Clinical Laboratory Science. All rights reserved.
Corresponding author: Chang-Eun Park Department of Biomedical Laboratory Science, Molecular Diagnostics Research Institute, Namseoul University, 91 Daehak-ro, Seonghwan-eup, Seobuk-gu, Cheonan 31020 , Korea

Tel: 82-41-580-2722

Fax: 82-41-580-2932

E-mail: eun2777@hanmail.net

Received: July 31, 2016

Revised $1^{\text {st: }}$ : August 21, 2016

Revised 2 ${ }^{\text {nd: }}$ : August 24, 2016

Accepted: August 25, 2016

\section{Introduction}

Human papillomavirus (HPV) is the causative agent for cervical cancer [1]. The cervical cancer screening was once a simple annual Pap smear. But recently used to the various sample preparation with ThinPrep, cervical brushing, formalin fixed tissue. In general, fourteen HPV genotypes (HPV 16, 18, 31, 33, 35, 39, 45, 51, 52, 56, 58, 59, 66, and 68) are considered pathogenic or "high-risk (HR)" for causing the development of cervical cancer [2]. Cytology-based cervical cancer screening was introduced decades ago and subsequently implemented in many industrialized countries. A virus genome exists inside the capsid, and harbors eight partially overlapping open reading frames. The HPV gene structure is being three regions: an early region (E), late region (L), and a long control region (LCR) [3]. 
Cervical intraepithelial neoplasia (CIN) is a premalignant lesion and divided into three stages $(1,2$, and 3$)$. It is estimated that, in $70 \%$ of affected women, CIN $2 \sim 3$ was progress to cervical cancer after 10 20 years [4].

Generally screening techniques for HPV were widely used to cervical lesions by cervical smear or visual inspection used to screen women. These tests can be used alone or in a sequence (e.g. HPV test followed by a cervical smear when HPV positive) [5]. Recently, HPV genotyping using a reverse blot hybridization assay (REBA) in atypical squamous cells of undetermined significance (ASCUS) cytology samples. Therefore, the REBA test is a useful method to detect HR-HPV genotypes [6,7]. In 2012, WHO committed to developing recommendations for screen-and-treat strategies to prevent cervical cancer and commissioned a series of reviews to inform those recommendations [8].

The E6 and E7 are oncoproteins that play a roles in cancer progression. The oncoprotein from $\mathrm{E} 6$ binds to $\mathrm{p} 53$, its can be the DNA repair, inhibits apoptosis, Oncoprotein E7 binds to retinoblastoma $(\mathrm{Rb})$ protein, which is a well-known tumor suppressor, and promotes dysregulation of the cell cycle. Additionally, oncoprotein E7 also interacts with several cellular proteins other than $\mathrm{Rb}$ protein, and is involved in apoptosis inhibition [9,10].

Using a DNA chip test, we evaluated the clinical efficacy of HPV genotype based on cervical abnormalities. HPV genotyping using self-collected samples was feasible and well accepted, and showed sensitivity and specificity comparable to those achieved using clinician-collected samples [11].

Recent population-based studies in the United States have shown that $96 \%$ of cervical cancers, $93 \%$ of anal cancers, $64 \%$ of vaginal cancers, $51 \%$ of vulvar cancers, $36 \%$ of penile cancers, and $63 \%$ of oropharyngeal cancers are attributable to HPV [12]. Several screening methods focusing on the detection of HPV have emerged in recent years, as commercial assays that identify women who harbor cervical infections with at least one of 12 14 high-risk HPV (HR-HPV) types, which are associated with most cases of pre-invasive and cervical cancer.

In previous [13], the nested reverse transcription (RT) multiplex PCR protocol for the combined detection of E6/E7
mRNA of the $18 \mathrm{HPV}$ types $6 / 11,16,18,31,33,35,39,42,43$, $44,45,51,52,56,58,59,66$ and 68. Also, researchers were demonstrated its potential as a sensitive diagnostic tool for cervical intraepithelial neoplasia (CIN) [14].

The Aptima HPV assay involves three consecutive steps, which take place in a single tube: target capture specimen processing; target amplification by transcription-mediated amplification (TMA) [15], and detection of the amplification products by the hybridization protection assay (HPA) [16]. The assay incorporates an internal control for nucleic acid capture, amplification, and detection, as well as operator or instrument error. After cell lysis the target mRNA is isolated from the specimen by sequence-specific capture oligomers that also contain a deoxyadenosine tail. Many reported that being performed to prevalence of HPV positive ratio, for preventing the development of cervical cancer [17-19].

We are showed that investigation of HPV genotype distribution with general hospital visitors in Seoul area, to guide $\mathrm{HPV}$ vaccine and randomized asymtomatic women.

\section{Materials and Methods}

\section{Subjects}

A total 5,614 including women participated in the present study covering the 2015 year. All cervical vaginal specimens came from woman who underwent routine physical examinations at the general hospital in Seoul area. None of the enrolled women had any previous history of HPV infection or any subjective symptoms for cervical diseases, the relevant subject characteristics of age distribution which ranged from 22 to 71 years. The study was approved by institutional review board at N University (NSU-1160428-01).

\section{Sample collection}

Cervical specimens were collected with a disposable cervical cell collector. The sampling head of the brush was placed into a $5 \mathrm{~mL}$ ThinPrep ${ }^{\circledR}$ PreservCyt solution vial (Hologic Inc., Marlborough, MA, USA) and kept at $4^{\circ} \mathrm{C}$ for no more than one week before DNA extraction. The samples were collected while the patients were counseling by instruction of medication. Sample types were cervical 
brushing and ThinPrep.

\section{HPV DNA extraction}

Vaginal swab samples were collected and added to $5 \mathrm{~mL}$ of phosphate buffered saline (PBS) and vortexed vigorously to separate exfoliated cell from a cytobrush, followed by the removal of cytobrush. The cell suspensions were centrifuged for $5 \mathrm{~min}$ at 7,500 $\mathrm{g}$ and the cell pellet resuspended in $1 \mathrm{~mL}$ of PBS and transferred to a microcentrifuge tube for repeat centrifugation. The suspension was discarded and the pellet resuspended in $200 \mu \mathrm{L}$ of PBS. DNA extraction was performed with a proteinase $\mathrm{K}(10 \mathrm{mg} / \mathrm{mL})$. The extraction procedure was carried out according to the guidelines of the manufacturer. Purified DNAs were adjusted to $100 \mu \mathrm{L}$ using a spin column and the DNA stored at $-20^{\circ} \mathrm{C}$.

\section{4. $P C R$ amplification}

HPV detection and genotyping were performed by DNA amplification, flow-through hybridization and a gene chip using the HPV DNA chip kit (AGBIO Diagnostics Co., Chuncheon, Korea). Nested PCR was performed on a GeneAmp 9700 system (Thermo Fisher Scientific Inc., Waltham, MS, USA). The total volume for PCR was $25 \mu \mathrm{L}$ containing 200 ng DNA. This assay can detect 15 HR-HPV genotypes (HPV 16, 18, 31, 33, 35, 39, 45, 51, 52, 56, 58, 59, 66, 68 and 69), and 6 low risk (LR) HPV genotypes (HPV 6, 11, 34, 40, 42, 43 and 44). The thermocycler was programmed as follows: 9 min at $94^{\circ} \mathrm{C} ; 5$ cycles of $1 \mathrm{~min}$ at $94^{\circ} \mathrm{C}, 2 \mathrm{~min}$ at $50^{\circ} \mathrm{C}, 30 \mathrm{sec}$ at $72^{\circ} \mathrm{C} ; 35$ cycles of $1 \mathrm{~min}$ at $94^{\circ} \mathrm{C}, 2 \mathrm{~min}$ at $50^{\circ} \mathrm{C}$, $15 \mathrm{sec}$ at $72^{\circ} \mathrm{C}$; and $2 \mathrm{~min}$ at $72^{\circ} \mathrm{C}$. The isolation of DNA was evaluated with the amplification of $\beta$-globin. Negative and positive controls were performed at the end of each PCR assay. After PCR amplification, $5 \mu \mathrm{L}$ of PCR aliquot was layered and electrophoresed on 2.5\% agarose gels and stained with ethidium bromide.

\section{DNA chip}

The HPV Chip kit (AGBIO Diagnostics Co., Chuncheon, Korea), which is a PCR based DNA microarray system, was used for HPV genotyping. HPV chip for the detection of HPV genotypes has attained an approved license issued in accordance with biopharmaceuticals and medical devices from the Korean Food and Drug Administration (KFDA) in 2004 (approval of permission: KFDA 2004-07-20). The procedure of the experiment consists of hybridization, washing, scanning. Eighty $\mu \mathrm{L}$ of hybridization buffer was pre-heated at $40^{\circ} \mathrm{C}$ for $5 \mathrm{~min}$. The PCR products $(25 \mathrm{~mL})$ were denaturated at $95^{\circ} \mathrm{C}$ for $5 \mathrm{~min}$, The mixed solution of premixture and hybridization buffer was put in the each hybridization well on the slide and sealed with cellophane tape to reduce evaporation. Hybridization was performed at $40^{\circ} \mathrm{C}$ for $30 \mathrm{~min}$. To eliminate unbound probes, slides were washed twice. Remaining on the slides was evaporated at room temperature. Hybridized HPV DNA was visualized using a DNA Chip scanner (Scanarray 4000, GSI Lumonics, Ottawa, Canada).

Single infection HPV (must be at least one of $150 \mathrm{bp}$ or 180 bp is detected) the results of the PCR and the $\beta$-globin (200 bp) This is all positive, marker spot all four detected and other 22 pairs spot one pairs of the its detected in the spot and the value of signal-to-background ratio (SBR) is more than 2.5.

Multiple infection HPV (must be at least one of 150 bp or $180 \mathrm{bp}$ is detected) the results of the PCR and the $\beta$-globin (200 bp) This is all positive, marker spot all four detected and other 22 pairs spot two pairs of the its detected in the spot and the value of SBR is more than 2.5.

Other type were HPV (must be at least one of $150 \mathrm{bp}$ or 180 $\mathrm{bp}$ is detected) the results of the PCR and the $\beta$-globin (200 bp) This is all positive, marker spot in four two SBR value of more than 4 , with the exception of the marker spot 22 pairs of SBR is less than the spot value of 2.5 .

The SBR values were HPV spot intensity / Background intensity. HPV amplicons can be hybridized with corresponding type-specific oligonucleotide probe and visualized on HPV DNA Chip slides as double positive spots (Fig. 1).

\section{Statistical analysis}

The level of statistical significance was defined as having a $p$-value of less than 0.05 or 0.01 . Data were analyzed using PASW version 17.0 (SPSS Inc., Chicago, IL, USA). A chi-square test was used to check for the difference between data collected for different distribution values and the level of 
significance was set the $p<0.05$ which is statistical significance level.

\section{Results}

\section{HPV prevalence in clinical patients for 2015 year}

A total of $18.6 \%$ of the 5,614 participants tested positive for one or more of the HPV DNA genotypes, with $14.0 \%$ (784/5,614) testing positive for only HR-HPV, 3.1\% $(176 / 5,614)$ for only LR-HPV, and $1.5 \%(88 / 5,614)$ for both HR-HPV and LR-HPV (Table 1). Infections with multiple types of HPV were observed in $10.0 \%(105 / 1,046)$ of the HR-HPV positive and $2.3 \%(24 / 1,046)$ of LR-HPV. Among these participants, $12.3 \%(129 / 1,046)$ were infected with multiple (Table 1).
A.

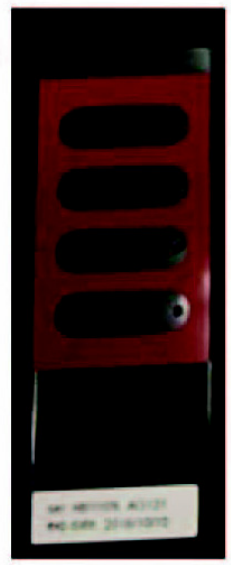

B.

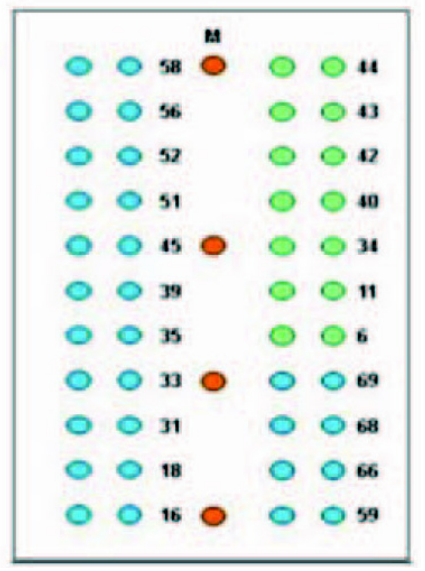

Fig. 1. HPV DNA chip slide (AGBIO Diagnostics Co.). HPV DNA chip kit (AGBIO Diagnostics Co.), which is a PCR-based DNA microarray system, was used for HPV genotyping. (A) HPV DNA chip slide consisting chambers. Each chamber contains 22 type-specific probes. (B) Scanning pattern of HPV DNA chip slide, Distribution of HPV genotypes in each number of slides. M: Internal standard, Number means the HPV genotypes.

\section{HPV genotype distribution single infection}

The distribution of HPV genotypes (single) in the enrolled women is summarized in Table 2. Fifteen HR-HPV genotypes were found, the most common being HPV 16, detected in $20.2 \%$ of the 679 patients (Table 2). HPV 58 and HPV 52 were the next two most common HR-HPV genotypes, The 3 genotypes were present in $49.5 \%$ of all the HR-HPV infected women. Among LR-HPV infections, HPV 42 was the most common genotype, which was significantly more prevalent than HPV 6 and HPV 11.

\section{HPV genotype distribution multiple infection}

The distribution of HPV genotypes (multiple) in the enrolled women is summarized in Table 3. Multiple of HR-HPV genotypes were found, the most common being HPV $16 / 66$ and HPV 56/58, detected in $8.4 \%, 7.3 \%$ of the 95 patients (Table 3). LR-HPV infections multiple type were HPV $40 / 44$.

\section{HPV infection as an age and sample type}

The highest HR-, LR-HPV prevalence were observed in young women below 30-39 years of age, which was significantly higher than the 50 59 years aged groups $(p<0.05)$, but was not very significantly different from the HPV prevalence in women older (Table 4). Those women between the ages of $<60$ years showed the lowest HPV prevalence. The cervices of the women infected with HPV were sample collected in the present study (Table 4). A ThinPrep sample type was highly positive the HPV infection finding for women infected with either HR-HPV or LR-HPV, observed in 65.2\% and $14.4 \%$.

Table 1. The prevalence of HPV genotype patterns

\begin{tabular}{|c|c|c|c|c|c|c|c|c|c|c|}
\hline \multirow{3}{*}{ Total } & \multirow{3}{*}{$\begin{array}{c}\text { Overall } \\
\text { HPV }\end{array}$} & \multicolumn{4}{|c|}{ HR-HPV (+) } & \multicolumn{4}{|c|}{ LR-HPV (+) } & \multirow{3}{*}{ Mixed infection* } \\
\hline & & \multirow{2}{*}{ Single } & \multicolumn{3}{|c|}{ Multiple } & \multirow{2}{*}{ Single } & \multicolumn{3}{|c|}{ Multiple } & \\
\hline & & & 2 & 3 & 4 & & 2 & 3 & 4 & \\
\hline 5,614 & $\begin{array}{l}1,046 \\
(18.6)\end{array}$ & $\begin{array}{c}679 \\
(12.1)\end{array}$ & $\begin{array}{c}95 \\
(1.7)\end{array}$ & $\begin{array}{c}9 \\
(0.2)\end{array}$ & $\begin{array}{c}1 \\
(0.02)\end{array}$ & $\begin{array}{c}152 \\
(2.7)\end{array}$ & $\begin{array}{c}24 \\
(0.4)\end{array}$ & 0 & 0 & $\begin{array}{c}86 \\
(1.5)\end{array}$ \\
\hline
\end{tabular}

Values were $\mathrm{n}(\%)$, Other type were 550 (10).

*Mixed infection of HR (high risk)- and LR (low risk)- HPV. 


\section{Discussion}

The challenge of HPV DNA chip technique is to determine which assay would offer the most favorable balance between detection of pap smear and false positive test results generated by high assay sensitivity for detection of often inconsequential HPV infections. Clinical sensitivity is

Table 2. The distribution of HPV single genotypes

\begin{tabular}{cc}
\hline HPV genotype & $\mathrm{n}(\%)$ \\
\hline HR-HPV & $679(100.0)$ \\
Total & $137(20.2)$ \\
16 & $42(6.2)$ \\
18 & $16(2.4)$ \\
31 & $23(3.4)$ \\
33 & $17(2.5)$ \\
35 & $24(3.5)$ \\
39 & $10(1.5)$ \\
45 & $59(8.7)$ \\
51 & $73(10.8)$ \\
52 & $49(7.2)$ \\
56 & $126(18.5)$ \\
58 & $14(2.1)$ \\
59 & $43(6.3)$ \\
66 & $45(6.6)$ \\
68 & $1(0.1)$ \\
69 & $152(100.0)$ \\
LR-HPV & $15(9.9)$ \\
Total & $4(2.6)$ \\
6 & $11(7.2)$ \\
11 & $30(19.7)$ \\
34 & $39(25.7)$ \\
40 & $26(17.1)$ \\
42 & $27(17.8)$ \\
43 &
\end{tabular}

Values were only single detected HPV genotype. different from the analytical sensitivity of a given test system, as a test with a good clinical sensitivity usually has a higher cut-off for being positive than the analytical detection threshold that separates signal from noise. Therefore, clinical trials are needed to define the cut-off for the clinical sensitivity. Clinically validated HR-HPV DNA assays usable for primary HPV-based cervical cancer screening. For various assays, noninferior sensitivity and specificity for the outcome CIN2+ and sufficient intra- and interlaboratory reproducibility has been required by following the validation protocol. An

Table 3. The frequency distribution of HPV multiple genotypes

\begin{tabular}{|c|c|c|c|}
\hline HR-HPV genotype & n (\%) & LR-HPV genotype & n (\%) \\
\hline Total & $66(69.5)$ & Total & $21(87.5)$ \\
\hline $16 / 18$ & $2(2.1)$ & $34 / 42$ & $3(12.5)$ \\
\hline $16 / 35$ & $4(4.2)$ & $40 / 42$ & $3(12.5)$ \\
\hline $16 / 58$ & $2(2.1)$ & $40 / 44$ & $13(54.2)$ \\
\hline $16 / 66$ & $8(8.4)$ & $42 / 43$ & 2 (8.3) \\
\hline $16 / 68$ & $4(4.2)$ & each 1 & $3(12.5)$ \\
\hline $18 / 51$ & $3(3.2)$ & & \\
\hline $18 / 52$ & $2(2.1)$ & & \\
\hline $18 / 56$ & $2(2.1)$ & & \\
\hline $18 / 58$ & $2(2.1)$ & & \\
\hline $31 / 66$ & $2(2.1)$ & & \\
\hline $33 / 68$ & $2(2.1)$ & & \\
\hline $35 / 52$ & $2(2.1)$ & & \\
\hline $45 / 58$ & $2(2.1)$ & & \\
\hline $51 / 56$ & $3(3.2)$ & & \\
\hline $51 / 58$ & $4(4.2)$ & & \\
\hline $51 / 68$ & $3(3.2)$ & & \\
\hline $52 / 58$ & $4(4.2)$ & & \\
\hline $52 / 68$ & $3(3.2)$ & & \\
\hline $56 / 58$ & $7(7.3)$ & & \\
\hline $58 / 66$ & $2(2.1)$ & & \\
\hline $58 / 68$ & $3(3.2)$ & & \\
\hline each 1 & $29(30.5)$ & & \\
\hline
\end{tabular}

Table 4. Age and sample type-related prevalence of HR- and LR-HPV single genotypes

\begin{tabular}{lccc}
\hline \multicolumn{1}{c}{ Variable } & HR-HPV & LR-HPV \\
\hline Age & & & Total \\
$>19$ & $2(0.2)$ & $0(0)$ & $2(0.2)$ \\
$20 \sim 29$ & $165(19.9)$ & $36(4.3)$ & $201(24.2)$ \\
$30 \sim 39$ & $313(37.7)$ & $70(8.4)$ & $383(46.1)$ \\
$40 \sim 49$ & $120(14.4)$ & $31(3.7)$ & $151(18.1)$ \\
$50 \sim 59$ & $49(5.9)$ & $8(1.0)$ & $57(6.9)$ \\
$<60$ & $30(3.6)$ & $7(0.9)$ & $37(4.5)$ \\
Total & $679(81.7)$ & $152(18.3)$ & $831(100.0)$ \\
Sample type & $133(16.0)$ & $32(3.9)$ & $165(19.9)$ \\
Cervical brushing & $4(0.5)$ & $0(0)$ & $4(0.5)$ \\
Formalin fixed tissue & $542(65.2)$ & $120(14.4)$ & $662(79.6)$
\end{tabular}


important issue in the validation process of HPV tests is the origin of the samples and the status of the cervical cell specimen included in the series of cases with disease (CIN2+) or disease ( $\leq$ CIN1) [20].

HPV testing in general is an established tool for the triage of borderline cytology results and national cervical cancer screening guidelines have been adapted accordingly in many countries [21]. Most widely-used commercial or in-house methods are mentioned in an historical perspective. however, some might have been missed accidentally. Molecular detection of HPV DNA or RNA or protein even with its limitation is a powerful tool when evaluated properly in terms of clinical sensitivity and specificity. Method validation with proper reference materials and lab accreditation are necessary, they can guarantee for the analytical value of molecular HPV detection tests [22]. It has to be pointed out that, if considering the number of tests sold instead of the number of different tests manufactured in a given country, the would probably be different to compare CIN detection.

HPV assays: Hybrid capture 2 HPV DNA testing (Qiagen, Gaithersburg, MD, USA), Cobas HPV Test (Roche Diagnostics, Pleasanton, CA, USA), CLART HPV2 Assay Genomica, Madrid, Spain), and APTIMA HPV Test (Hologic/Gen-Probe, San Diego, CA, USA). Small differences in clinical characteristics were found for the four HPV assays in abnormal cytology aged $\geq 30$ years. At younger ages, APTIMA was somewhat less sensitive for high-grade CIN than the three HPV DNA assays [23]. HR-HPV DNA detection in urine by the Trovagene HPV HR test in three different fractions from first void and initial stream urine was highly sensitive for the detection of CIN2+ in colposcopy patients. HR-HPV testing via non-invasive, simple, and highly acceptable urine sampling may be a viable method for cervical cancer screening [24].

The great majority of complete HPV diagnostic assays currently on the market are validated to be used for testing cervical scrapings only, and on top of that for scrapings collected by a single or usually up to no more than three different specimen collection devices. we urgently need an evaluation of the performance of as many commercial HPV tests as possible on a broader range of alternative clinical specimens; for example, other types of self-collected an genital samples (different brushes, swabs and sponges, tampons), oral swabs, saliva, anal swabs, penile swabs, Guthrie-type filter paper [25].

High-risk HPV E6 protein inhibits expression of miR-34a through the p53-pathway to increase virus-infected cell survival and enhance cancer cell proliferation and metastasis. Undoubtedly, miR-34a is a highly promising biomarker of HPV-associated cancers [26].

A combined methylation assay for HPV 16, HPV 18, HPV 31, HPV 33 and four host genes has shown promise for triage of HPV positive women, but further studies are needed, particularly in comparison to established markers, to assess the value of HPV methylation for triage. If successful, a HPV methylation assay that covers the majority of carcinogenic types could provide combined HPV test results. These HPV genotyping and HPV methylation results in a single assay that would provide risk stratification for placing women in all but the highest risk groups [27].

Boers et al. [28] were identified new CIN2/3-specific methylation markers using genome-wide DNA methylation analysis. The diagnostic performance of our new methylation panel shows higher specificity, Methylation levels of 8/9 genes were significantly higher in carcinoma compared to normal scrapings. These 9 genes (ZSCAN1, ST6GALNAC5, ANKRD18CP, PAX2, CDH6, GFRA1, GATA4, KCNIP4, and LHX8) were selected for further diagnostic evaluation in cervical scrapings.

Moreover, as the other HPV genotype previously reports were rare in Korea [29,30], Further studies are required with the HPV DNA chip test before the nationwide adoption of the vaccines. The HPV was a ubiquitous sexually transmitted infection, which often goes undiagnosed. Nevertheless, its wide prevalence has helped uncover some of the negative ramifications of infection with the virus. The role of HPV in the success of assisted reproduction is less clear-cut; several studies show a decreased pregnancy rate for intrauterine insemination and in vitro fertilization in women with HPV compared to controls, while other studies show no correlation [31].

Interventions with a systems-based approach have also been studied and are encouraged by the CDC as a mechanism 
to reach the Healthy People 2020 goal. The benefits and harms of the treatments found in the present review can be considered along with the values and preferences of patients, resources, and feasibility issues to decide which treatment to provide [32,33]. The data were also used to inform recommendations about screen-and-treat strategies to prevent cervical cancer.

\section{요 약}

인간 유두종 바이러스(HPV)에 의한 감염은 자궁경부암의 원인 이다. $\mathrm{HPV} \mathrm{DNA}$ 의 세포 검사에서의 변화는 향후 더 도전적으로 발 전을 기대한다, $\mathrm{HPV}$ 유전자형의 감염에 대한 새로운 $\mathrm{HPV}$ 의 DNA (22종) chip 검사는 최근 한국에서 많이 개발되었다. 이 연구의 목 적은 서울 지역에서 HPV 감염의 빈도와 유전자형 분포를 알아보고 자 하였다. 지난 2015년 한 해 동안 서울지역 종합병원 내원객을 대 상으로 총 5,614 검체의 검사에서 HPV 유전자형은 1,596 (28.4\%) 에서 검출되었다, 이중 한 종류의 유전자형은 가진 검체 $(n=831)$ 중 고위험 HPV는 679 (42.5\%), 저위험 HPV는 152 (9.5\%)로 나타났 다. 이중 자주 발견 유전자형은 HPV-16 (16.5\%), 58 (15.2\%), 52 (8.8\%), 51 (7.1\%), 56 (5.9\%) 순이었다. 혼합 유전자형 $(\mathrm{n}=219)$ 중 2 종 $(n=176,11.0 \%), 3$ 종 $(n=37,5.9 \%), 4$ 종 $(n=2,0.1 \%)$ 이 나타났 다 이에 본 연구는 종합 병원 방문자의 $\mathrm{HPV}$ 감염을 조사하였다. 이 러한 연구 결과는 HPV 전국적으로 분포 및 백신의 도입을 안내하 는 데 이용될 수 있을 것으로 사료되며 진료에 중요한 정보를 제공 하며 역학적 추가 연구가 요구된다.

\section{Acknowledgements: None}

Funding: None

Conflict of interest: None

\section{References}

1. zur Hausen H. Papillomaviruses in the causation of human cancers: a brief historical account. Virology. 2009;384:260-265.

2. Burd EM. Human papillomavirus and cervical cancer. Clin Microbiol Rev. 2003;16:1-17.

3. Zheng ZM, Baker CC. Papillomavirus genome structure, expression, and posttranscriptional regulation. Front Biosci. 2006;11:2286-2302.

4. Castle PE, Schiffman M, Wheeler CM, Solomon D. Evidence for frequent regression of cervical intraepithelial neoplasia-grade 2. Obstet Gynecol. 2009;113:18-25.

5. Mustafa RA, Santesso N, Khatib R, Mustafa AA, Wiercioch W,
Kehar R, et al. Systematic reviews and meta-analyses of the accuracy of HPV tests, visual inspection with acetic acid, cytology, and colposcopy. Int J Gynaecol Obstet. 2016;132:259265.

6. Kim S, Lee IS, Lee D. Human papillomavirus prevalence and genotype distribution in normal and ASCUS specimens: comparison of a reverse blot hybridization assay with a DNA chip test. Biomed Sci Lett. 2015;21:32-39.

7. Lee D, Kim G, Kim S, Park S, Wang HY, Park S, et al. Human papillomavirus distribution among women in Western Shandong province, East China using reverse blot hybridization assay. Biomed Sci Lett. 2015;21:69-76.

8. Santesso N, Mustafa RA, Schünemann HJ, Arbyn M, Blumenthal PD, Cain J, et al. World Health Organization Guidelines: Treatment of cervical intraepithelial neoplasia 2-3 and screen and treat strategies to prevent cervical cancer. Int J Gynecol Obstet. 2016;132:252-258.

9. Doorbar J. Molecular biology of human papillomavirus infection and cervical cancer. Clin Sci (Lond). 2006;110:525-541.

10. Palefsky JM, Holly EA. Molecular virology and epidemiology of human papillomavirus and cervical cancer. Cancer Epidemiol Biomarkers Prev. 1995;4:415-428.

11. Dijkstra MG, Heideman DA, van Kemenade FJ, Hogewoning KJ, Hesselink AT, Verkuijten MC, et al. Brush based self-sampling in combination with GP5+/6+-PCR-based hrHPV testing: high concordance with physician-taken cervical scrapes for HPV genotyping and detection of high-grade CIN. J Clin Virol. 2012;54:147-151.

12. Cobos C, Figueroa JA, Mirandola L, Colombo M, Summers G, Figueroa A, et al. The role of human papilloma virus (HPV) infection in non-anogenital cancer and the promise of immunotherapy: a review. Int Rev Immunol. 2014;33:383-401.

13. Sotlar K, Stubner A, Diemer D, Menton S, Menton M, Dietz K, et al. Detection of high-risk human papillomavirus E6 and E7 oncogene transcripts in cervical scrapes by nested RT-polymerase chain reaction. J Med Virol. 2004;74:107-116.

14. Sotlar K, Diemer D, Dethleffs A, Hack Y, Stubner A, Vollmer N, et al. Detection and typing of human papillomavirus by e6 nested multiplex PCR. J Clin Microbiol. 2004;42:3176-3184.

15. Hill CS. Molecular diagnostic testing for infectious diseases using TMA technology. Expert Rev Mol Diagn. 2001;1:445-455.

16. Nelson NC, Kacian DL. Chemiluminescent DNA probes: a comparison of the acridinium ester and dioxetane detection systems and their use in clinical diagnostic assays, Clin Chim Acta. 1990;194:73-90.

17. Coutlée F, Ratnam S, Ramanakumar AV, Insinga RR, Bentley J, Escott N, et al. Distribution of human papillomavirus genotypes in cervical intraepithelial neoplasia and invasive cervical cancer in Canada. J Med Virol. 2011;83:1034-1041.

18. Thibaudeau E, Fortin B, Coutlée F, Nguyen-Tan P, Weng X, Audet ML, et al. HPV prevalence and prognostic value in a prospective cohort of 255 patients with locally advanced HNSCC: A single-centre experience. Int J Otolaryngol. 2013;2013: 437815. doi: 10.1155/2013/437815.

19. Suthipintawong C, Siriaunkgul S, Tungsinmunkong K, Pientong C, Ekalaksananan T, Karalak A, et al. Human papilloma virus prevalence, genotype distribution, and pattern of infection in 
Thai women. Asian Pac J Cancer Prev. 2011;12:853-856.

20. Arbyn M, Snijders PJ, Meijer CJ, Berkhof J, Cuschieri K, Kocjan BJ, et al. Which high-risk HPV assays fulfil criteria for use in primary cervical cancer screening? Clin Microbiol Infect. 2015; 21:817-826.

21. Saslow D, Solomon D, Lawson HW, Killackey M, Kulasingam SL, Cain J, et al. American society for colposcopy and cervical pathology, and American society for clinical pathology screening guidelines for the prevention and early detection of cervical cancer. Am J Clin Pathol. 2012;137:516-542.

22. Kroupis C, Vourlidis N. Human papilloma virus (HPV) molecular diagnostics. Clin Chem Lab Med. 2011;49:1783-1799.

23. Rebolj M, Lynge E, Ejegod D, Preisler S, Rygaard C, Bonde J. Comparison of three human papillomavirus DNA assays and one mRNA assay in women with abnormal cytology. Gynecol Oncol. 2014;135:474-480.

24. Senkomago V, Des Marais AC, Rahangdale L, Vibat CR, Erlander MG, Smith JS. Comparison of urine specimen collection times and testing fractions for the detection of high-risk human papillomavirus and high-grade cervical precancer. J Clin Virol. 2016;74:26-31.

25. Vorsters A, Van den Bergh J, Micalessi I, Biesmans S, Bogers J, Hens A, et al. Optimization of HPV DNA detection in urine by improving collection, storage, and extraction. Eur J Clin Microbiol Infect Dis. 2014;33:2005-2014.

26. Chen J, Zhao KN. HPV-p53-miR-34a axis in HPV-associated cancers. Ann Transl Med. 2015;3:331. doi: 10.3978/j.issn.
2305-5839.2015.09.39

27. Lorincz AT, Brentnall AR, Scibior-Bentkowska D, Reuter C, Banwait R, Cadman L, et al. Validation of a DNA methylation HPV triage classifier in a screening sample. Int $\mathrm{J}$ Cancer. 2016;138:2745-2751.

28. Boers A, Wang R, van Leeuwen RW, Klip HG, de Bock GH, Hollema $\mathrm{H}$, et al. Discovery of new methylation markers to improve screening for cervical intraepithelial neoplasia grade $2 / 3$. Clin Epigenetics. 2016;8:29.

29. Lee YJ, Jung JH, Jung DY. The relationship between papanicolaou smear test and human papilloma virus DNA chip test in the uterine cervix. Korean J Clin Lab Sci. 2011;43:26-32.

30. Lee KO, Seong HS, Chung SJ, Jung NY, Lee HJ, Kim KT. Genotype frequency of human papillomavirus determined by PCR and DNA sequencing in Korean women. Korean J Clin Lab Sci. 2006;38:99-104.

31. Pereira N, Kucharczyk KM, Estes JL, Gerber RS, Lekovich JP, Elias RT, et al. Human papillomavirus infection, infertility, and assisted reproductive outcomes. J Pathog. 2015;2015:578423.

32. Park MS, Cho HW, Kim JG, Bae NY, Oh DS, Park HH. Genotype analysis of human papilloma virus infection in accordance with cytological diagnoses. Korean J Clin Lab Sci. 2015;47:39-45.

33. Kim GH, Kim SH, Park SY, Park SJ, Lin H, Ren Y, et al. Human papillomavirus prevalence and distribution according to age among Korean and Chinese women. Korean J Clin Lab Sci. 2015;47:259-266. 